\title{
JUAL BELI ONLINE DALAM PERSPEKTIF ISLAM
}

\author{
Achmad Zurohman*, Eka Rahayu
}

\begin{abstract}
Human life is inseparable from buying and selling activities. Along with the times, buying and selling is not only done in the real market but online using the internet. This study aims to analyze how Islam views online buying and selling. This study uses library research to provide a comprehensive explanation of the advantages and disadvantages of online buying and selling. Online buying and selling is a buying and selling activity that does not require sellers and buyers to come face to face. The buyer makes a payment first then proceed with the delivery of the goods. The Taudhibul abkammembagi divides the legal conditions of buying and selling into two, namely 1) the seller and the buyer must be willing and there is no element of compulsion, and 2) trade in sacred and beneficial goods. Through online sales, sellers and buyers get many benefits. Sellers do not need a lot of money for promotions, etc. Buyers can access goods anywhere without the limitations of time and place, provided they are connected to the internet. The disadvantage of buying and selling online is that it is prone to frand if the buyer is not careful and careful. The buyer must be able to select and choose a store that can be trusted. Online buying and selling in Islam is also called greeting, where the buyer pays first then the seller sends the goods. Muamalah is permissible in Islam as long as it is in harmony and the conditions.
\end{abstract}

Kata kunci: buying and selling, online, Islam

* Dosen Institut Ilmu Keislaman Zainul Hasan Genggong Kraksaan probolinggo 


\section{Pendahuluan}

Jual beli dalam Islam dapat diartikan dengan tukar menukar harta dengan cara tertentu yang bermanfaat (Syaifullah, 2014). Harta yang dimaksud adalah materi atau manfaat. Manfaat dari suatu benda dapat diperjualbelikan. Jual beli merupakan transaksi yang didalamnya terdapat dua unsur yaitu ijab dan qabul. Melakukan kegiatan jual beli, sesama umat manusia dapat saling tolong menolong yang sangat dianjurkan dalam Islam. Firman Allah dalam Surat An-Nisa ayat 29 yang berbunyi:

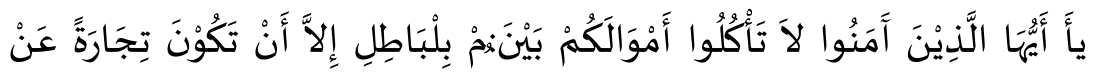

Artinya: Wahai orang-orang beriman, janganlah kalian memakan hartaharta kalian dengan cara yang batil, kecuali dengan perdagangan yang kalian saling ridha (QS. An-Nisa: 29).

Ayat tersebut menjelaskan bahwa Allah memperbolehkan manusia untuk melakukan transaksi harta orang lain melalui perdagangan berdasarkan ridha dan saling ikhlas.

Saat ini, internet sangat berpengaruh pada perkembangan bisnisbisnis yang sudah dijalankan. Bisnis berkembang dengan pesat melalui kegiatan transaksi jual beli media online yang dikenal dengan belanja online(Hardiawan, 2013; Wulandari, 2015).Jual beli online dikenal dengan kemudahannya dalam berbelanja tanpa menghabiskan waktu dan tenaga. Perdagangan yang dilakukan di dunia maya tidak memberikan batasan ruang dan waktu antara pembeli dan penjual (Salim, 2017). Berbisnis dengan cara online dilakukan atas dasar kepercayaan karena pembeli dan penjual tidak saling bertatap muka dalam melakukan transaksi (Fitria, 2017).

Pekerti \& Herwiyanti(2018) menyatakan bahwa dengan kemudahan bertransaksi secara online dapat menimbulkan berbagai masalah yakni: 1) kualitas barang yang dijual karena pembeli tidak melihat langsung barang yang akan dibeli; 2) berpotensi penipuan karena pembeli sudah membayar dan barang tidak kunjung tiba, dan 3) berpotensi untuk gagal membayar karena barang yang dibeli sudah tiba dan tidak kunjung dibayar.

Berdasarkan pengamatan kepada pelaku jual beli online yang membeli 
barang melalui instagram, tidak mendapatkan barangnya sementara uang sudah ditransfer ke pembeli. Kejadiantersebut dapat meruntuhkan kepercayaan pembeli untuk berbelanja online. Jual beli tersebut tidak memenuhi definisi jual beli karena gagalnya tukar menukar barang yang bermanfaat untuk pengguna dan melanggar perjanjian yang sudah di kesepakatan(Susiawati, 2017).

Berdasarkan kejadian yang sudah disebutkan di atas maka artikel ini akan menganalisis jual beli online menurut persfektif Islam. Berbagai macam rukun dan syarat yang dibutuhkan dalam transaksi jual beli online sehingga tidak ada pihak yang dirugikan. Selain itu, pembeli dapat berhati-hati dan teliti dalam melakukan transaksi jual beli agar sesuai dengan rukun dan syarat jual beli dalam syariat Islam (Susiawati, 2017).

\section{Metode Penelitian}

Pendekatan penelitian yang digunakan dalam tulisan ini yaitu penelitian kepustakaan. Penelitian ini dilakukan dengan menelusuri berbagai literatur terkait dengan konsep jual beli online dalam perspektif Islam. Kemudian dari berbagai literatur tersebut digunakan untuk membahas bagaimanakan perspektif Islam dalam memandang jual beli online terutama berbasis media sosial. Hal ini bertujuan untuk memberikan penjelasan yang komprehensif mengenai kelebihan dan kekurangan jual beli online berbasis media sosial yang saat ini sedang marak seiring dengan perkembangan teknologi internet.

\section{Pembahasan}

\section{Definisi Jual Beli}

Jual beli menurut bahasa adalah menukarkan sesuatu dengan sesuatu (muqabilat syai'i bi sayi'i). Sedangkan menurut syar'i artinya menukar harta dengan harta menurut cara-cara tertentu. Adapun definisi jual beli menurut fuqaha yang dikutip oleh Abu Al-rahman adalah menukarkan sesuatu dengan harga(Apipudin, 2016). Pemahaman ini didasarkan pada firman Allah surat Yusuf ayat 20 yang berbunyi:

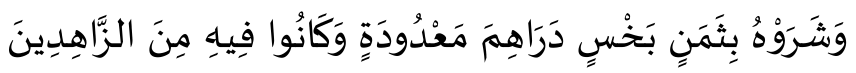

Artinya: "Dan mereka menjualnya (Yusuf) dengan harga rendah, yaitu 
beberapa dirham saja, sebab mereka tidak tertarik kepadanya" (QS. Yusuf: 20).

Tafsiran ayat tersebut adalah orang-orang musafir itu membeli Yusuf dari tangan penimba air dan teman-temannya dengan harga yang sangat murah. Harga yang kurang dari semestinya yaitu hanya beberapa dirham saja sekitar dua puluh atau dua puluh dua dirham. Mereka saudara-saudara penimba air itu merasa tidak tertarik hatinya kepada Yusuf.Kemudian rombongan musafir itu membawa Yusuf ke negeri Mesir selanjutnya Nabi Yusuf dijual oleh orang yang membelinya dengan harga dua puluh dinar, dua pasang terompah dan dua buah baju. (Tafsir Al-Jalalain, Yusuf 12:20). Jual beli diartikan dengan tukar menukar barang berharga secara suka sama suka atau peralihan kepemilikan dengan cara pergantian menurut bentuk yang diperbolehkan.

Berbagai ulama madzhab juga mendefinisikan jual beli, meskipun terdapat perbedaan namun subtansi dan tujuan masing-masing definisi sama. Ulama Hanafiah menjelaskan bahwa jual beli adalah menukarkan benda dengan dua mata uang yaitu emas dan perak dan semacamnya. Tukar menukar barang dengan uang atau semacamnya menurut cara yang khusus. Ulama Hanafiyah mengungkapkan definisi secara khusus bahwa jual beli harus melalui ijab (ungkapan membeli dari pembeli) dan qabul (pernyataan menjual dari penjual), atau boleh melalui saling memberikan barang dan harga dari penjual dan pembeli. Akan tetapi harta yang diperjualbelikan haruslah yang bermanfaat bagi manusia. Apabila jenis-jenis barang yang tidak memiliki manfaat tetap diperjual-belikan, maka jual belinya tidak sah.

Beberapa definisi di atas dapat diketahui bahwa secara garis besar jual beli adalah suatu perjanjian tukar menukar barang atau benda yang memiliki nilai secara ridha di antara kedua belah pihak.Salah satu pihak menerima benda dan pihak lainnya menerima uang sebagai kompensasi barang, serta dipertukarkan dengan alat ganti yang dapat dibenarkan sesuai dengan perjanjian dan ketentuan yang telah dibenarkan syara' dan disepakati. Islam mempertegas legalitas dan keabsahan jual beli secara umum, serta menolak dan melarang konsep riba (Salim, 2017).

Terkait dengan jual beli online adalah jual beli barang dan jasa yang dilakukan melalui media elektronik, khususnya melalui internet atau 
secara online.Fitria(2017) menyatakan bahwa jual beli via internet yaitu sebuah akad jual beli yang dilakukan dengan menggunakan sarana eletronik baik berupa barang maupun berupa jasa. Jual beli via internet adalah transaksi yang disepakati dengan menentukan ciri-ciri tertentu, membayar harganya terlebih dahulu sedangkan barangnya diserahkan kemudian.

Jual beli online sering kali disebut juga dengan online shopping, atau jual beli melalui media internet. Ardhinata (2015) mendefinisikan jual beli online sebagai satu set dinamis teknologi, aplikasi dan proses bisnis yang menghubungkan perusahaan, konsumen, komunitas tertentu melalui transaksi elektronik dan perdagangan barang, pelayanan dan informasi yang dilakukan secara elektronik.

Berdasarkan pengertian di atas dapat disimpulkan bahwa jual beli via internet adalah jual beli yang dilakukan melalui media elektronik. Untuk melakukan transaksi jual beli penjual dan pembeli tidak harus bertemu secara langsung atau saling menatap muka secara langsung. Pembeli dapat menentukan ciri-ciri dan jenis barang yang diinginkan kemudian membayar sesuai dengan harga yang tertera. Kemudian penjual menyerahkan barang yang akan dijual belikan.

Terkait dengan perpspektif Islam mengenai jual beli online yang saat ini telah menjadi suatu hal yang sangat lumrah dilakukan dalam transaksi jual beli, terutama jual beli online berbasis kepada media sosial. Maka dari itu perlu diketahui apakah dalam jual beli online tersebut telah memenuhi rukun dan syarat, sehingga jual beli dapat dikatakan sah oleh syara'. Ada perbedaan pendapat mengenai rukun jual beli, menurut jumhur ulama' dengan ulama Hanafiyah. Rukun jual beli menurut jumhur ulama'berpendapat bahwa rukun jual beli ada empat, yaitu: Orang yang berakad atau al-muta'aqidain (penjual dan pembeli), Sigat (lafal ijab dan qabul), Ma'qud 'alaih (barang yang dibeli) dan Nilai tukar pengganti barang.Sedangkan, berdasarkan ulama Hanafiyah hanya satu, yaitu ijab (ungkapan membeli dari pembeli) dan qabul (ungkapan menjual dan menjual). Menurut ulama Hanafiyah, orang yang berakad, barang yang dibeli, dan nilai tukar barang termasuk ke dalam syarat-syarat jual beli, bukan rukun jual beli (Salim, 2017).

Terdapat beberapa syarat sah jual beli yang harus dipenuhi, berikut dirangkum dari kitab Taudbibul abkam 4/213-214 (Salim, 2017). Pertama, 
persyaratan yang berkaitan dengan pelaku praktek jual beli, baik penjual maupun pembeli, yaitu: hendaknya kedua belah pihak melakukan jual beli dengan ridha dan sukarela, tanpa ada paksaan. Sesuai dengan kalam Allah ta'ala dalam QS. An-Nisaa': 29, Kedua belah pihak berkompeten dalam melakukan praktek jual beli, yakni dia adalah seorang mukallaf dan rasyid (memiliki kemampuan dalam mengatur uang), sehingga tidak sah transaksi yang dilakukan oleh anak kecil yang tidak cakap, orang gila atau orang yang dipaksa. Hal tersebut merupakan salah satu bukti keadilan agama ini yang berupaya melindungi hak milik manusia dari kezaliman, karena seseorang yang gila, safiib (tidak cakap dalam bertransaksi) atau orang yang dipaksa, tidak mampu untuk membedakan transaksi mana yang baik dan buruk bagi dirinya sehingga dirinya rentan dirugikan dalam transaksi yang dilakukannya.

Kedua, yang berkaitan dengan barang yang diperjualbelikan, syaratsyaratnya yaitu: objek jual beli baik berupa barang jualan atau harganya merupakan barang yang suci dan bermanfaat, bukan barang najis atau barang yang haram, karena barang yang secara dzatnya haram terlarang untuk diperjualbelikan, Objek jual beli merupakan hak milik penuh, seseorang bisa menjual barang yang bukan miliknya apabila mendapat izin dari pemilik barang. Rasulullah shallallahu 'alaihi wa sallam bersabda:

$$
\text { عندك ليس ما تب لا }
$$

Artinya: "Janganlab engkau menjual barang yang bukan milikmu." (HR. Abu Dawud 3503, Tirmidzi 1232, An Nasaa'i VII/289, Ibnu Majah 2187, Ahmad III/402 dan 434; dishahihkan Syaikh Salim bin 'Ied Al Hilaly).

Seseorang diperbolehkan melakukan transaksi terhadap barang yang bukan miliknya dengan syarat pemilik memberi izin atau rida terhadap apa yang dilakukannya, karena yang menjadi tolok ukur dalam perkara muamalah adalah rida pemilik. (Lihat Figh wa Fatawal Buyu' hal. 24). Hal tersebut ditunjukkan oleh persetujuan Nabi shallallahu 'alaihi wa sallam terhadap perbuatan Urwah tatkala beliau memerintahkannya untuk membeli kambing buat beliau (HR. Bukhari bab 28 nomor 3642). Objek jual beli dapat diserahterimakan, sehingga tidak sah menjual burung yang terbang di udara, menjual unta atau sejenisnya yang kabur dari kandang dan semisalnya. Transaksi yang mengandung objek jual 
beli seperti ini diharamkan.Hal tersebut karena mengandung gharar (spekulasi) dan menjual barang yang tidak dapat diserahkan, Objek jual beli dan jumlah pembayarannya diketahui secara jelas oleh kedua belah pihak sehingga terhindar dari gharar. Abu Hurairah berkata: "Rasulullah shallallahu 'alaihi wa sallam melarang jual beli hashaath (jual beli dengan menggunakan kerikil yang dilemparkan untuk menentukan barang yang akan dijual) dan jual beli gharar" (HR. Muslim: 1513).

Selain itu, tidak diperkenankan seseorang menyembunyikan cacat/ aib suatu barang ketika melakukan jual beli. Rasulullah shallallahu 'alaihi wa sallam bersabda:

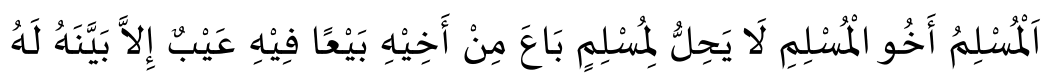

"Seorang muslim adalah saudara bagi muslim yang lain. Tidak halal bagi seorang muslim menjual barang dagangan yang memiliki cacat kepada saudaranya sesama muslim, melainkan ia harus menjelaskan cacat itu kepadanya" (HR. Ibnu Majah nomor 2246, Ahmad IV/158, Hakim II/8, Baihaqi V/320; dishahihkan Syaikh Salim bin 'Ied Al Hilali).

Fiqh muamalah Islam menjelaskan jual beli secara online ada kesamaan dengan jual beli barang pesanan yang disebut salam. Dimana penjual menjual sesuatu yang tidak dilihat zatnya, hanya ditentukan dengan sifat barang itu ada didalam pengakuan si penjual.Dikatakan salam karena ia menyerahkan uangnya terlebih dahulu sebelum menerima barang daganganya, dan ini termasuk jual beli yang sah jika memenuhi semua persaratan yang telah ditentukan oleh Islam.

\section{Kelebihan Jual Beli On-line}

Adapun keuntungan yang di dapat oleh konsumen antara lain: 1) pembeli tidak perlu mendatangi toko untuk mendapatkan barang, cukup terkoneksi dengan Internet, pilih barang dan selanjutnya melakukan pemesanan barang, dan barang akan di antar kerumah; 2) menghemat waktu dan biaya transportasi berbelanja, karena semua barang belanjaan bisa dipesan melalui perantara media internet khususnya situs yang menjual belikan barang apa yang ingin di beli; 3) pilihan yang ditawarkan sangat beragam, sehingga sebelum melakukan pemesanan kita dapat membandingkan semua produk dan harga yang ditawarkan oleh 
perusahaan; 4) melalui perantara via internet pembeli dapat membeli barang di Negara lain secara online;

5) harga yang ditawarkan sangat kompetitif, karena tingkat persaingan dari pelaku usaha melalui media internet sehingga mereka bersaing untuk menarik perhatian dengan cara menawarkan harga serendah-rendahnyacukup melakukan pemasaran barang jualan melalui media online; 6) jual beli dapat dilakukan tanpa terikat pada tempat dan waktu tertentu. Jual beli online merupakan bisnis yang dapat dilakukan kapanpun dan dimanapun, selama tersedia fasilitas untuk mengakses internet. Contohnya, seorang pengusaha melakukan perjalanan bisnis, kemudian pada saat itu juga ada konsumen yang ingin memesan barang sedangkan pengusaha tersebut tidak sedang di kantor, pengusaha tersebut mengajurkan agar melakukan transakasi via internet dan barang pesanan dapat diambil esoknya;

7) modal awal yang di perlukan relatif kecil. Modal yang di perlukan adalah fasilitas akses internet dan kemampuan mengoperasikannya. Banyak penyedia jasa yang menawarkan media promosi, baik yang berbayar maupun yang gratis.Contohnya, Agung termasuk pengusaha pemula dengan modal pemasaran yang sedikit, namun pada saat bersamaan Agung juga menerapkan pemasaran lewat internet sehingga tidak terlalu mengeluarkan modal; 8) jual beli online dapat berjalan secara otomatis. Pelaku usaha hanya melakukan bisnis jual beli ditempat di beberapa jam saja setiap harinya sesuai dengan kebutuhan. Selebihnya di gunakan untuk melakukan aktivitas yang lain; Selebihnya di gunakan untuk melakukan aktivitas yang lain; Contohnya, andi seorang pengusaha namun juga merupakan seorang guru disalah satu SMP ternama di Jakarta, namun itu tidak menganggu usahanya karena Andi menerapkan penjualan online sejak 2 tahun yang lalu;

9) akses pasar yang lebih luas. Dengan adanya akses pasar yang lebih luas, potensi untuk mendapatkan pelanggang baru yang banyak semakin besar. Contohnya, Penggunaan internet sekarang semakin luas, pasar internet merupakan salah satu pasar modern yang diterapkan sekarang, dengan hadirnya seperti zalora, berniaga.com, olx, dll. Membuktikan bahwa pasar online telah terbuka bebas; 10) pelanggang lebih mudah mendapatkan informasi yang diperlukan dengan online. Komunikasi antar pelaku usaha dan konsumen akan menjadi lebih mudah, praktis dan hemat 
waktu serta biaya; Contohnya, Banyaknya website yang menyediakan layanan jual beli online memungkinkan untuk dapat mengakses dengan mudah spesifikasi barang yang ingin dibeli;

10) meningkatkan efesiensi waktu, terutama jarak dan waktu dalam memberikan layanan kepada konsumen selaku pembeli. Contohnya, Seorang pengusaha dan konsumen yang berteransaksi 2 negara yang berbeda, dan 11) pengehematan dalam berbagai biaya operasional. Beberapa komponen biaya seperti trasportasi, komunikasi, sewa tempat, gaji karyawan, danyang lainnya akan lebih hemat. Dengan adanya penghematan biaya dalamberbagai komponen tersebut, secara otomatis akan meningkatkan keuntungan. Contohnya, dengan adanya fasilitas online untuk melakukan transaksi jual beli online sehingga seorang pengusaha dapat menghemat biaya operasional terutama tempat yang berbeda dan sangat jauh, dengan hanya biaya kirim saja yang menjadi tangunggang.

Berdasarkan uraian di atas, maka penulis dapat menyimpulkan bahwa keuntungan jual beli via internet tidak hanya didapatkan oleh konsumen, penjual pun mendapatkan keuntunggan.Penjual tidak perlu susah payah dalam menyewa toko untuk menjual dagangannya, disamping itu penjual dapat manfaakan teknologi dapat menjangkau kepada calon pembeli di seluruh dunia, sehingga biaya promosi akan lebih efesien. Di sisi lain, kelebihan yang mendasar yang ada pada transaksi jual beli via internet ini adalah si pembeli dan penjual sama-sama memiliki tingkat kejujuran dan kepercayaan yang tinggi sehingga keduanya tidak pernah merasa dirugikan.

\section{Kekurangan Jual Beli On-line}

Disamping keuntungan yang didapat penjual dan pembeli, adapun kerugiannya adalah sebagai berikut: 1) produk tidak dapat dicoba. Dalam jual beli via internet produk yang ditawarkan adalah bermacammacam dan beragam, dan semua produk tersebut tidak dapat dicoba, bila pembeli mencari pakaian, terutama pakaian atau yang lain maka pembeli tidak bisa mencoba. Akan tetapi pengecer online menyediakan berbagai ukuran. Pembeli harus memberikan pertimbangan terhadap ukuran yang tercantum di toko berbasis web. Pembeli tidak dapat mengetahui tingkat 
kehalusan dan sebagainya;

2) standar dari barang tidak sesuai. Salah satu kerugian yang di dapat pembeli dalam jual beli via internet adalah barang tidak sama dengan aslinya.Di situs toko berbasis web yang ditampilkan adalah foto barang yang di tawarkan. Kesamaan dari barang foto yang kita lihat di sekitar monitor tidak seratus persen persis sama. Mungkin yang mirip dengan barang awal hanya90\% saja karena ditambah dengan pengaruh dari pencahayaan; 3) pengiriman mahal.Jual beli via internet yang terjadi melalui media elektronik yang berjauhan tentunya produk yang dibeli tidak selalu langsung kita dapat mengambil. Pemilik toko online masih memerlukan jasa pengiriman, dan yang menentukan pengiriman produk yang memiliki barang-barang tersebut pengiriman jasa JNE, TIKI, Pos Indonesia, dan sebagainya;

4) risiko penipuan, dalam jual beli via intenet, toko berbasis web memang rentanakan penipuan. Pastikan belanja di website online yang dapat diandalkan. Bahayanya uang akan diteruskan ke penjual meskipun produk tidak dikirim dan tidak pernah dikirimkan selamanya, dan 5) barang yang dibeli akan tiba lebih lama apabila toko berada di tempat yang jauh.

\section{Jual Beli Online dalam Perspektif}

Jual beli secara online memiliki kesamaan dengan jual beli pesanan yang disebut dengan salam. Jual beli salam adalah transaksi yang dilakukan dengan menyerahkan uang terlebih dahulu sebelum barang diterima. Transaksi seperti ini dianggap sah apabila memenuhi persyaratan yang sudah ditentukan Islam. Dasar hukum salam dalam Islam dikategorikan jual beli yang diperbolehkan. Hal tersebut berdasar pada Al-Qur'an surat Al-Baqarah ayat 282 yang berbunyi:

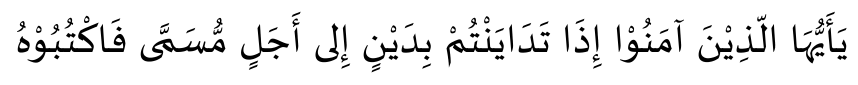

Artinya: "Hai orang-orang yang beriman, apabila kamu bermuamalab tidak secara tunai untuk waktu yang ditentukan, hendaklab kalian menuliskannya" (QS. Al-Baqarah: 282).

Ayat tersebut dapat menjadi landasan hukum jual beli online dalam Islam. Selain itu, jual beli yang tidak tunai heknaknya segera ditulis agar 
terhindar dari kesalahpahaman atau mencegah terjadinya kelupaan dari salah satu pihak.

Jual beli salam menurut Islam terdapat beberapa rukun yang harus terpenuhi, diantaranya: 1) sighat, yaitu ijab dan qabul; 2) aqiddani, yaitu orang yang melakukan transaksi jual beli, dalam hal ini penjual dan pembeli, dan 3) objek barang yang ingin di transaksi terkait harga dan barang yang dipesan. Adapun syarat yang harus dipenuhi yaitu: 1) uang dibayarkan terlebih dahulu; 2) barang menjadi utang bagi penjual; 3) barang diberikan sesuai dengan waktu yang sudah disepakati; 4) barang yang sudah dijanjikan harus ada, jika belum ada maka transaksi jual beli tidak sah; 5) kejelasan barang sangat diperlukan seperti ukuran, takaran dan jumlah, ketiga komponen tersebut memang sudah lumrah dan berlaku bagi proses jual beli, dan 6) sifat-sifat barang diketahui dengan jelas agar tidak menjadi perselisihan dikemudian hari.

\section{Simpulan}

Jual beli via internet adalah jual beli yang dilakukan melalui media elektronik.Untuk melakukan transaksi jual beli penjual dan pembeli tidak harus bertemu secara langsung atau saling menatap muka secara langsung. Pembeli dapat memilih barang yang diinginkan, membayar sejumlah harga yang tertera. Kemudian penjual menyerahkan barang yang akan dijual belikan. Syarat sah jual beli dalam Islam yaitu 1) penjual dan pembeli ridho dan tidak ada unsur keterpaksaan dari pihak manapun, dan 2) barang yang diperjualbelikan harus yang mengandung manfaat dan suci serta barang milik sendiri. Jika milik orang lain harus ada keridhoan dari pemilik barang.

Keuntungan jual beli via internet dapat dirasakan oleh kedua belah pihak. Penjual tidak perlu susah payah dalam menyewa toko untuk menjual dagangannya, disamping itu penjual dapat manfaakan teknologi dapat menjangkau kepada calon pembeli di seluruh dunia, sehingga biaya promosi akan lebih efesien. Kekurangannya yaitu pembeli harus lebih selektif dan berhati-hati dalam melakukan transaksi ditakutkan terjadi penipuan. Melakukan transaksi secara online diperboleh dalam Islam asalkan sesuai dengan rukun dan syarat yang telah ditentukan. 


\section{Daftar Pustaka}

Al-Jaziri, A. (1994). Fiqib Empat Madzhab. Semarang: CV. Asy Syifa.

Apipudin. (2016). Konsep Jual Beli dalam Islam ( Analisis Pemikiran Abdu al-Rahman al-Jaziri dalam Kitab al-Fiqh Al al- Madahib alArba'ah ). ISLAMINOMIC, V(2), 1-11.

Ardhinata, A. (2015). Keridhaan (Antaradhin) dalam Jual Beli Online (Studi Kasus UD. KUNTAJAYA Kabupaten Gresik). JESIT, 2(1).

Fitria, T. N. (2017). Bisnis Jual Beli Online (Online Shop) dalam Hukum Islam dan Hukum Negara. Jurnal Ilmiah Ekonomi Islam, 3(1), 52-62.

Hardiawan, A. C. (2013). Pengarub Kepercayaan, Kemudahan, dan Kualitas Informasi Terbadap Keputusan Pembelian Secara Online. Universitas Diponegoro.

Pekerti, R. D., \& Herwiyanti, E. (2018). Transaksi Jual Beli Online dalam Perspektif Syariah Madzhab Asy-Syafi' i.Jurnal Ekonomi, Bisnis, Dan Akuntansi (JEBA), 20(2), 1-12.

Salim, M. (2017). Jual Beli secara Online menurut Pandangan Hukum Islam. Al-Daulah, 6(2), 371-386.

Susiawati, W. (2017). Jual Beli dan dalam Konteks Kekinian. Jurnal Ekonomi Islam, 8(2), 171-184.

Syaifullah. (2014). Etika Jual Beli dalam Islam. Hunafa: Jurnal Studia Islamika, 11(2), 371-388.

Wulandari, F. M. (2015). Jual Beli Online yang Aman dan Syar'i (Studi terhadap Pandangan Pelaku Bisnis Online di Kalangan Mahasiswa dan Alumni Fakultas Syari'ah dan Hukum UIN Sunan Kalijaga). Az Zarqa', 7(2), 201-220. 